\title{
Dictionaries in modern life
}

\author{
Sharipov Sohib Salimovich ${ }^{1}$, Nematova Mohibegim Fazliddinovna ${ }^{2}$ \\ ${ }^{1,2}$ Bukhara State University, Uzbekistan
}

Email: sharipov_s@umail.uz

\begin{abstract}
The article considers the issues of lexicography, as well as the role of dictionaries. The reasons for the lack of translation equivalents in dictionaries are considered here.
\end{abstract}

Keywords: dictionary, bilingual dictionaries, internet, correspondence.

\section{INTRODUCTION}

Dictionary? What is the role of dictionaries in our life? Without realizing it, we often turn to dictionaries, looking for answers to our questions, without thinking where, when, and under what circumstances this or that dictionary was created. What was the reason for creating the dictionary.

Dictionary - this is a historical account of the lives of people, their thoughts, aspirations, troubles and joys. Being an element of national culture, many dictionaries of the people are marked in the dictionaries of the dictionary.

Member of South American lexicographical organization C.Landau said "Making dictionaries doesn't mean they should be perfect thinking and being without mistakes, this type of activity needs to be intellectual. In addition, the process of creating a dictionary must be approved by the author. "[1]

It is impossible not to agree with the expressions of a scientist about labor efficiency and selfassurance of this type of work.

The role of dictionaries in the modern world of great. The general function of all dictionaries is fixation, systematization, accumulation and storage of knowledge.

Lexicography is a simultaneous science and art. The lexicographer is a scientist so long as he is careful to read and understand (enlarge) the dictionaries and the artist is at a glance to be able to do so. "In general, vocabulary work, based solely on semantics, requires a special subtle perception of the language, requires ... a very special talent, which along some line is probably akin to writing talent." [2] (Shcherba, 1958, p. 76)

Today, the role of dictionaries in the spiritual life of society is more and more understood, in the conception of the cultural heritage of the people. As V. Kozyrev and V.D.Chernyak remark " a tremendous decrease in the general level of speech culture makes it very important to distinguish the role of the word as it is very important and irreplaceable. " [3]

Dictionaries have a comparatively late emergence. They are subject to a period which is ensured by the timely opening of a book printing in the middle of the XV century. However, in the preceding centuries, people provided glossaries; these were handwritten lists of foreign and unusual dictionaries, which came to be confronted in manuscripts in other languages, especially in Greek wines. A scientist or simply a scribe, having determined the value of an unintelligible dictionary, wrote it between lines or on the floor; A separate such mark was given the name Glocka (from the Greek glossa "language, dictionary"). The earliest voices are known with the deepest nuances (for example, Sumerian glosses of the 25 th century BC). With a functional point of view, in dictionaries it was implemented as the so-called meta-language function of the language, i.e. the use of the language for the purpose of discussing the language itself, and not the outside world. Hand-written glossaries were used at regular intervals. Many copies were made from them, and one day later, when the book was printed, the books were cheaper, the book was counted as a total of four prints [4].

A huge number of different types of dictionaries serve to provide information: explanatory and translated, terminological and dictionaries of difficulties, dictionaries of foreign words and etymological, dictionaries of synonyms and orthographic. Most often you have to turn to bilingual translation dictionaries, without 
which it is not possible to learn any language. Immersion in any professional sphere requires familiarity with the terms of this science and access to terminological dictionaries (often small terminological reference books accompany books on various branches of knowledge).

A large role is given to the explanatory dictionary. An explicit dictionary is provided in writing, which may be necessary in one or another situation; An explicit dictionary can instill confidence in the correctness of a particular or other verbal action. .[5]

Since the fast pace of modern life is consistent with the constant changes in the language, the speakers must be updated in accordance with the requirements of the time. New dictionaries should be included in the frequently published dictionaries in the order of their completion. The fullness and scrupulousness are equally important.

Depending on the type of lexical units represented in the dictionary, and, above all, on the way they are described, all dictionaries are divided into two large groups: encyclopedic (encyclopedias) and linguistic (philological). The main emphasis of linguistic dictionaries is aimed at describing the word of its meaning, features of use, compatibility. The role of encyclopedic dictionaries is not to explain the meaning of the word as such. The object of encyclopedic dictionaries are descriptions of concepts, facts and realities. In linguistic dictionaries, a word is described in terms of its language and speech characteristics (interpretation, etymological data, etc.), and in an encyclopedia, a dictionary entry can include a variety of information transmitted in text and visual form (in the form of drawings, photographs, maps).

Encyclopedic dictionaries are of two types: general and special. All linguistic dictionaries can be divided into three types, depending on the number of languages represented in them:

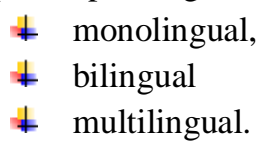

The latter two types are often also called translational dictionaries. As an example of a monolingual linguistic dictionary, you can call the Longman Dictionary of Contemporary English, Ozhegov's Dictionary of Russian.? Volume 4 “Academic Dictionary of the Russian Language”, etc.

A wide range of work for lexicographers results in the creation of bilingual, or translational dictionaries, a practical value and a wide range of labor. The main task of the dictionary of this type is to ensure that the text is understood in a foreign language, its translation into a native language. Russian lexicography (as well as lexicography of the majority of developed countries that are actively involved in various forms of fossil fusion) is removed.

In the age of globalization and the media, the Internet plays a big role in our lives. At this time, there are several online views of the dictionary provided on various sites. Among them, the most popular ones are Multitran, Multilex, etc. The Multitran dictionary covers 900 topics, 7 languages, 8,000,000 terms, and there is a chance to add to the rest. It is necessary to enter the line to search for the necessary dictionary and, having pressed one button, to receive the translation options. The obvious advantage of these resources is that there are a large number of thematic dictionaries in the dictionary articles, which allows you to choose the best option.

The Yandex Yandex system is intended for users to use only a few vocabulary dictionaries with a different meaning, but not the other way around. Dictionaries giving the interpretation of the dictionary in the original language. Only English speakers of the English language Webster, Oxford, Cambridge, Bartleby, Onelook will be indispensable for students to work on more advanced stages of learning.

ABBYY Lingvo - this is the most complete electronic dictionary, which contains a modern vocabulary from different thematic areas, as well as universal, so and special. More than a dictionary included in Lingvo (80\% of them were published in 2003-2006), you can get detailed information about each dictionary with an example. Scientific and technical progress is not worth it. Electronic dictionaries appeared on our market relatively recently, but with every day I use all the great popularity.

So why is it better to use in learning foreign languages - electronic dictionaries or printed? What are their advantages and disadvantages?

Printed publications provide transcriptional knowledge and their pronunciation, as well as the most common reading rules. Some printed editions also give some information about the grammar of the language being studied. The advantage of printed dictionaries is that they are not tied to a socket, and will 
help in learning English even with a candle. Inconsistency also exists. The printed dictionary has a large size. To find the right dictionary, you need to spend a certain amount of time looking for it. Insofar as such a dictionary has a restriction on the size, then the information on the right dictionary is usually written very short and with a small text.

For quick search of a dictionary in a printable dictionary, you need the knowledge of alphabet, in electronic - a knowledge of the location of the keyboard on the keyboard. Searching for the desired dictionary in the electronic dictionary takes a fraction of a second. In addition, the dictionary allows you to find the right dictionary, even if we will only show it, even if we say it with an error. By every dictionary, we can get the most detailed information, since there is no restriction on electronic terms in terms of volume. With the text, there is also no problem - we can expand the page to the entire screen, enlarge the font and the contrast of the text. The necessary data can always be printed.

\section{CONCLUSION}

In summary, the great advantage of online dictionary is that they significantly reduce the search time for dictionaries, and the whole world can be used. This factor is of great importance for the modern man, who appreciates his time. In addition, the main online availability of non-online dictionary is that they always give us relevant information. If the printed dictionary starts to be deleted immediately after printing, then the online dictionaries are constantly updated and changed.

Looking at the devil, you can say that the printed products and electronic publications, having their own advantages and disadvantages, perfectly complement each other. Namely, they supplement, but do not replace!

\section{REFERENCES}

1. Landau S.I. Dictionaries The Art and Graft of Lexicografi-N.- Y., 1989

2. Л.В.Щерба Избранные работы по русскому языку. Учпедгиз , 1957.

3. Козырев В.А., Черняк В.Д. Русская лексикография. - М.: Дрофа, 2004.-288 с.

4. Нигматова Л.Х. Из истории лексикографии. Научный журнал «Бухарский вестник» № 3, 2019

5. Гак В.Г. Лексикография; Словарь. - Лингвистический энциклопедический словарь. М., 1990

6. В.И. Максимова. Русский язык и культура речи. Москва 2003 г.

7. Новый большой англо-русский словарь под общим руководством акад. Ю.Д. Апресяна (онлайн версия)http://www.classes.ru/dictionary-english-russian-Apresyan-term-10983.htm

8. http://www.multitran.ru/c/m.exe? $11=1 \& 12=2 \& s=$ growing+nations

9. http://encyclopaedia.biga.ru/enc/liberal_arts/SLOVAR.html

10. http://www.dict.t-mm.ru/lopatin

11. http://nauka.relis.ru/27/0411/27411048.htm 